\section{Science Abstracts}

THE two volumes of Science Abstracts of 1934 have now been issued. Each is 7-8 per cent smaller than the corresponding volume of 1933 , but the decrease in the number of abstracts is in neither case so great. The Physies volume has 1,561 pages, more than 300 of which are devoted to the subject index, the supplementary index of apparatus and instruments and the author index. The Electrical Engineering volume has 905 pages, more than 150 of which are occupied by subject index and author index. Each volume is indispensable to those who would keep themselves up to date in the field it covers.

\section{British Health Resorts}

THE British Health Resorts Association has issued a new edition of its official handbook ("British Health Resorts: Spa, Seaside, Inland (including New Zealand, South Africa, and Canada)". London : J. and A. Churchill, Ltd. 1s.). The handbook is edited by Dr. Fortescue Fox, and contains a foreword by the Minister of Health, Sir Hilton Young, and it is claimed that there is no other publication like it in Great Britain or any other country. Authoritative information is given of every health resort in the British Empire, and some useful pages are devoted to winter health resorts in Great Britain. The information concerning each resort includes an illustration, and details of climate, the diseases for which it is suitable, and particulars of attractions and accommodation.

\section{Announcements}

Sir Henry Lyons has been appointed member and chairman of the Advisory Council of the Science Museum in succession to Sir Richard Glazebrook, who has resigned.

According to The Times of April 12, Mr. Martin Lindsay has been awarded the Alexandre de la Roquette Gold Medal by the French Geographical Society for his leadership of the British TransGreenland Expedition, 1934.

Prof. Emil Abderhalden, director of the Physiological Institute at Halle, has been elected a foreign member of the Lombardy Society of Medicine, and a corresponding member of the Pontifical Academy of Sciences in Vatican City.

The Committee of the A. Chauveau Foundation has recently awarded the prize in veterinary science to M. C. Dubois, director of the veterinary services of Gard, for his work on undulant fever in animals.

ON April 9, Lady Oppenheimer opened an interesting exhibition of books about trees, collected mainly by certain publishers, under the auspices of the society of "Men of the Trees", and displayed at its headquarters at 10 Victoria St., Westminster, S.W.1.
In addition to modern books and pamphlets, many interesting old books have been gathered together, including a fourteenth century MS. of St. Isidore's "Etymologia", a kind of encyclopædia of all knowledge as it was known in the sixth and seventh centuries, including the properties and care of trees.

THE Tomarkin Foundation is arranging the seventh International Medical Post-Graduate Congress, under the auspices of the University of Brussels, to be held at Brussels on September 12-19, and at Spa on September 20-October 2. The Congress is officially approved by the General Commissariat of the World Exhibition which will be held in Brussels at the same time. Further particulars can be obtained from the Secretary, Tomarkin Foundation, Faculty of Medicine, 97, rue aux Laines, Brussels.

ON April 10, Sir John Gilmour, the Home Secretary, opened the new Metropolitan Police Laboratory for the scientific investigation of crime, which has been established at Hendon. The members of the Committee which has been formed to advise on the development of the Laboratory are: Lord Atkin, Lord Dawson of Penn, Lord Trenchard, Sir Russell Scott (Permanent Under-Secretary of State, Home Office), Sir Edwin Deller (Principal of the University of London), Sir Bernard Spilsbury, Sir Frank Smith (Secretary, Department of Scientific and Industrial Research), Sir Robert Robertson (Government Chemist), and Mr. Hugh Lett (senior surgeon to the London Hospital).

Messrs. Bernard Quaritch, Ltd., 11 Grafton Street, W.1, have celebrated this year by issuing an extremely interesting list of five hundred rare and choice books (Cat. 500). Among these is a number of early scientific and medical classics and rarities. To the bibliophile, this catalogue with its bibliographical detail and its thirty illustrations will make a special appeal; and librarians and collectors with funds at their disposal will find many treasures here to tempt them. Prices range from 15s. upwards, but it must be realised that this is emphatically not a bargain hunter's catalogue, since the average price of the books offered is nearly $£ 100$ each.

Applications are invited for the following appointments, on or before the dates mentioned :-A research assistant to the British Cast Iron Research Association-The Director, 21 St. Paul's Square, Birmingham, 3 (April 23). An assistant lecturer in building in the College of Technology, Manchester-The Registrar (May 3). An advisory economist in the Department of Agriculture, University of Leeds-The Registrar (May 7). A professor of obstetrics and gynæcology in the University of Hong Kong-The Secretary, Universities Bureau of the British Empire, 88a, Gower Street, London, W.C.1. Two radio research assistants in the Research Laboratories, G.E.C., Ltd., Wembley, Middlesex-The Director. 